\title{
Komunikasi Kesehatan Dokter dan Pasien Berbasis Kearifan Lokal Sipakatau di Masa Pandemi
}

\author{
Andi Hasan Al Husain \\ Jurusan Pendidikan Agama Islam, Fakultas Pendidikan Agama Islam, \\ Sekolah Tinggi Agama Islam Al Gazali Bulukumba \\ Jl. A. Mappijalan, No. 23, Kabupaten Bulukumba, Sulawesi Selatan, 92511 Indonesia \\ Corresponding author: a.hasanalhusain@gmail.com
}

\begin{abstract}
The pandemic period raises concerns for medical workers who are infected with the COVID-19 virus because patients are not open to extracting information on their illnesses. This research aims to find interpersonal communication strategies implemented by doctors in the anamnesis process during the COVID-19 pandemic in Makassar. The research method used is descriptive qualitative, using an interpretive paradigm using Goffman's dramaturgy theory and using the Sipakatau or concept in its analysis. The selection of informants in this study were health workers who work like doctors who do not treat COVID-19 patients. To determine this, researchers used the snowball sampling technique. The data collection techniques use in-depth interviews via Whatsapp video calls, literature studies, internet searching. The results of this study indicate that selfpresentation in backstage is not too different from the front stage. The doctor's self-presentation on the front stage wore simple clothes such as a shirt and did not emphasize his identity as a doctor. This is done to support an attitude of equality with patients and to support the success of doctors in gathering information in the history-taking process, doctors use a communication strategy. The substance of this study found a new concept of health communication between doctors and patients based on local wisdom Sipakatau and recommended to hospitals and doctors to implement the concept of health communication based on local wisdom. Keywords: Communication of Sipakatau; Communication Strategy; Dramaturgy; Patient History
\end{abstract}

\begin{abstract}
Abstrak
Masa pandemik menimbulkan kekhawatiran bagi tenaga medis tertular virus COVID-19 yang disebabkan tidak terbukanya pasien dalam penggalian informasi pada panyakit yang diderita. Penelitian ini bertujuan untuk menemukan strategi komunikasi interpersonal yang diterapkan oleh para dokter dalam proses anamnesis di masa pandemi COVID-19 Di Kota Makassar. Metode penelitian yang digunakan adalah kualitatif deskriptif, dengan menggunakan paradigma interpretatif dengan menggunakan teori Dramaturgi dari Goffman serta menggunakan konsep Sipakatau dalam analisisnya. Pemilihan informan dalam penelitian ini adalah tenaga kesehatan yang berprofesi sebagai dokter yang tidak menangani pasien COVID-19, untuk penentuanya peneliti menggunakan teknik snowball sampling. Adapun teknik pengumpulan data dengan menggunakan wawancara mendalam melalui video call Whatsapp, studi pustaka, internet searching. Hasil penelitian ini menunjukkan bahwa presentasi diri dalam back stage tidak terlalu berbeda dengan front stage. Presentasi diri dokter pada panggung depan menggunakan pakaian yang sederhana seperti baju kemeja, dan tidak terlalu menonjolkan identitas sebagai dokter semestinya. Hal ini dilakukan untuk mendukung sikap kesetaraan dengan pasien dan untuk menunjang keberhasilan dokter dalam menggali informasi dalam proses anamnesis, dokter menggunakan strategi komunikasi Sipakatau. Substansi penelitian ini menemukan konsep baru komunikasi kesehatan antara dokter dan pasien berbasis kearifan lokal Sipakatau dan memberi rekomendasi kepada rumah sakit dan dokter untuk menerapkan konsep komunikasi kesehatan berbasis kearifan lokal. Kata kunci: Komunikasi Sipakatau; Strategi Komunikasi; Dramaturgi; Anamnesis Pasien
\end{abstract}

\section{Pendahuluan}

Pandemi COVID-19 telah mengubah wajah dunia (Lestari \& Sularso, 2020). Pada hari minggu, tanggal 19 April 2020 pukul 12.00 WIB terdapat 32 tim medis yang meninggal di masa pandemi, tidak semua menunjukkan positif virus corona, tetapi berstatus sebagai pasien dalam pengawasan (databook, 2020). Terdapat juga 12 perawat yang meninggal, diduga tertular penyakit COVID-19 yang telah dikonfirmasi oleh organisasi Ikatan Dokter Indonesia (IDI) (Azanella, 2020). Total tenaga medis yang meninggal sebanyak 44 orang yang terkonfirmasi dari tenaga dokter dan perawat. 
Ada sebanyak 16 orang tenaga kesehatan meliputi dokter, perawat, dan tenaga pendukung seperti tenaga administrasi di Rumah Sakit Wahidin Sudirohusodo Kota Makassar yang menyandang Pasien Dalam Pengawasan (PDP) (Taufiqqurahman, 2020). Hal ini dikarenakan masyarakat yang baru saja pulang dari pusat episentrum COVID-19 masih belum sepenuhnya terbuka soal riwayat perjalanannya. Tim medis yang berperan dalam penanganan COVID-19 ini meliputi dokter spesialis, dokter umum, apoteker, petugas laboratorium, ahli gizi, dan perawat yang merupakan profesi yang rentan terpapar virus tersebut. Hal ini disebabkan karena tenaga kesehatan tersebut berada di garda terdepan dalam penanganan COVID-19. Terdapat juga 15 perawat yang meninggal, sebanyak 14 orang di antaranya diduga tertular penyakit COVID-19 yang telah dikonfirmasi oleh organisasi IDI (Ramadhan et.all, 2020). Total tenaga medis yang meninggal sebanyak 44 orang yang terkonfirmasi dari tenaga dokter dan perawat.

Kurangnya APD (Alat Pelindung Diri) menjadi faktor terbesar tertularnya tenaga medis oleh Orang dengan Tanpa Gejala (OTG). Di sisi lain Achmad Yurianto sebagai juru bicara pemerintah RI untuk Penanganan COVID-19 mengatakan bahwa ada tiga daerah yang menjadi episentrum baru kasus virus corona di Indonesia, antara lain DKI Jakarta, Jawa Timur, dan Sulawesi Selatan. Kasus ketiga kota tersebut tergolong besar, sehingga berita tersebut sempat membuat para tenaga medis di Indonesia cemas, karena virus telah tersebar di seluruh provinsi se-Indonesia dan tidak terdeteksinya para carrier virus corona yang telah melakukan riwayat perjalanan dari zona merah.

Risiko tertular virus tersebut dapat dikurangi dengan strategi komunikasi para tenaga medis dalam pembukaan diri pasien. Strategi komunikasi dokter sangat diperlukan dalam menangani pasien yang datang ke rumah sakit dan pusat kesehatan masyarakat (PKM). Pasien yang datang ke rumah sakit dengan keluhan menyerupai gejala COVID-19 sering mengalami ketakutan atau kekhawatiran, hingga tidak terbuka dalam proses anamnesis ketika menemui dokter di masa pandemi.

Beberapa kasus yang terjadi di RS X, kebanyakan pasien yang masih tidak terbuka dalam proses anamnesis sehingga menularkan virus corona kepada tenaga medis yang bertugas. Hal ini berdampak pada diagnosa dokter kurang tepatdanpasientidakdapattertanganidenganbaik.

Para tenaga medis yang bertugas harus merancang strategi dalam pembukaan diri pasien dengan memberikan presentasi diri sebagai tenaga medis baik, pasien membangun kepercayaannya dan nyaman dalam mengungkapkan dirinya pada proses anamnesis di masa pandemi sekarang.

Pada penelitian yang dilakukan Innayatillah (2016) membahas mengenai penerapan komunikasi efektif dokter penyakit dalam (internis) untuk proses anamnesis di Aceh, Inayatillah menemukan bahwa terdapat dua sisi penting, yaitu sisi pengumpulan informasi atau yang dikelan dengan anamnesis. Anamnesis merupakan penggalian informasi mengenai riwayat penyakit keluhan dan penyakit pasien. Anamnesis yang baik mempu mempermudah dokter dalam mendiagnosa pasien sehingga mampu memberikan obat dan tindakan yang tepat.

Pada tahun 2019 yang dilakukan oleh Kurniawan (2019) melakukan penelitian tentang peran anamnesis terhadap kesembuhan pasien cephalgia. Penelitian tersebut menemukan bahwa dengan proses anamnesis dokter mampu mencari tahu histori pasien yang menderita penyakit cephalgia. Penyakit cephalgia merupakan penyakit sakit kepala yang sering menyerang masyarakat, penyakit ini mampu dideteksi penyebabnya melalui proses anamnesis. Proses anamnesis tersebut dapat menggali tentang pola makan, pola tidur, tingkat depresi dan kecemasan yang yang dilakukan serta yang dirasakan pasien tersebut. Anamnesis atau wawancara medis harus mendapatkan informasi yang benar sebelum melakukan tahap diagnosa dan 
pemberian obat kepada pasien, karena penyakit cephalgia merupakan penyakit yang tidak disebabkan oleh gangguan mikro organisme (virus atau bakteri) yang menyerang organ tubuh, melainkan penyakit cephalgia disebabkan oleh dehidrasi, stress, hipotensi, anemia.

Setyorini (2019) melakukan riset tentang efektifitas komunikasi dokter dalam membangun kepercayaan pasien. Indah menemukan bahwa komunikasi interpersonal yang efektif adalah dengan dengan menggunakan pendekatan bahasa dan pendekatan psikologis. Melalui empat tahap seperti pra pemeriksaan, pemeriksaan, tahap informasi awal (anamnesis), dan tahap penyampaian informasi. Kepercayaan pasien timbul dikarenakan adanya komunikasi dokter yang mampu memberikan solusi atas permasalahan kesehatan yang dirasakan pasien. Komunikasi interpersonal di Klinik Nirmala Husada berjalan efektif antara dokter dan pasien dengan menerapkan sikap keterbukaan, empati, dukungan, sikap positif, dankesetaraan.

Berdasarkan 3 (tiga) riset yang telah dilakukan sebelumnya, terlihat bahwa untuk mendapatkan informasi pada wawancara medis atau dalam bahasa medisnya adalah anamnesia maka diperkukan komunikasi yang efektif antara dokter dan pasien. Pada penelitian ini peneliti tertarik untuk melakukan riset terhadap strategi dokter di Kota Makassar dalam menggali informasi dan membuka diri pasien dalam mengungkapkan keluhannya di masa pandemi.

\section{Komunikasi Kesehatan Berbasis Kearifan Lokal}

Ilmu komunikasi memiliki cakupan yang luas dalam membahas suatu fenomena, salah satunya adalah komunikasi kesehatan yang menjadi fokus dari ilmu komunikasi. Komunikasi kesehatan memiliki cakupan dalam konteks pembinaan kesehatan, pencegahan suatu penyakit, promosi bidang kesehatan, pengobatan, dan advokasi masyarakat tentang kesehatan (Salisah, 2011).
Salisah (2011) menjelaskan bahwa Ilmu komunikasi terkadang dibantu oleh disiplin ilmu lain untuk mengembangkan ataupun menjelaskan sebuah masalah, seperti halnya ilmu antropologi yang menaungi antropologi kesehatan. Antropologi kesehatan memusatkan fokus kepada aspek sosial budaya dan biologi dalam tingkah laku manusia. Aspek ini bertujuan untuk mememengaruhi kesehatan dan penyakit manusia, dalam artian bagaimana manusia mencari tahu tentang sebab-sebab penyakit, asal mulanya, cara pencegahan dan pengobatannya dalam suatu kelompok masyarakat tertentu.

Para ahli antropologi asal jerman yang meneliti tentang antropologi kesehatan menggunakan istilah etnomedisin untuk pengobatan tradisional yang tidak berkembang dari barat. Etnomedisin ini merupakan konsep dari antropologi yang menggunakan nilai-nilai lokal dalam pembinaan kesehatan, pencegahan suatu penyakit, promosi bidang kesehatan, pengobatan dan advokasi masyarakat tentang kesehatan.

Konsep di atas digunakan dalam penelitian ini untuk menganalisis komunikasi berbasis kearifan lokal Bugis-Makassar yakni Sipakatau untuk membuka diri pasien dalam proses anamnesis dimasa pandemi. Komunikasi yang baik mampu mengurangi risiko kesalahan diagnosis pada pasien (Khadijah \& Rizal, 2015) dan menjadi aspek penting dalam meningkatkan kesehatan masyatakat. Hal tersebut juga bertujuan untuk mengurangi kecemasan pasien khususnya dimasa pandemi.

\section{Teori Dramaturgi}

Goffman menyatakan kehidupan sosial manusia dapat dibagi menjadi dua wilayah, front stage backstage. Front stage atau wilayah depan diumpamakan panggung penampilan seorang aktor bagian depan yang dipertontonkan oleh khalayak ramai. Wilayah belakang diumpamakan panggung belakang seperti ruangan rias dan tempat wardrobe tempat para 
aktor tidak sedang melakukan perannya, tempat latihan atau mempersiapkan segala sesuatu untuk penampilannya di panggung depan (Mulyana, 2008). Pada dasarnya, untuk memenuhi suatu kebutuhan dalam berinteraksi, terkadang individu memainkan sebuah peran layaknya seorang aktor.

Panggung depan sebagai presentasi seseorang ketika berhadapan dengan orang lain, cenderung aktor memainkan peran tertentu sesuai kebutuhan. Pada saat individu berada di belakang panggung, maka cenderung tidak memainkan peran apapun dan menjadi diri sendiri. Hal inilah yang dinamakan panggung depan (front stage) dan panggung belakang (backstage) sesuai teori dramaturgi yang dikemukakan oleh Goffman (Mulyana, 2008).

Presentasi diri tersebut dilakukan ketika seseorang berinteraksi dengan orang lain dan bertujuan menghasilkan sebuah pengelolaan kesan yang diharapkan muncul pada diri orang lain, lewat pertunjukan diri yang mengalami setting di orang lain. Pada pertunjukkan aktor menggunakan beberapa atribut seperti kostum, tata rias, pernak-pernik, dan alat penunjang lainnya. Goffman menjelaskan bahwa individu yang menunjukkan suatu aktivitas untuk memengaruhi orang lain, yang bertujuan untuk menghasilkan sebuah identitas sosial definisi dan presentasi diri. Aktor mendefinisikan suatu situasi yang berpengaruh pada ragam interaksi secara layak atau tidak layak (Mulyana, 2008: 110).

Interaksi yang tercipta dari sebuah komunikasi melalui penggunaan bahasa verbal dan nonverbal, sehingga menyebabkan masuk pandangan komunikasi. Di mana bahasa telah menjadi posisi utama dalam berkomunikasi. Komunikasi adalah proses pengalihan pesan yang dilakukan seseorang melalui suatu saluran tertentu untuk orang lain dengan mengharapkan efek timbal balik, karena inti dari komunikasi adanya interaksi dalam proses pertukaran informasi. Komunikasi dikatakan sebagai proses karena komunikasi itu bersifat dinamis, dan selalu terjadi perubahan dalam interaksinya (Liliweri, 2003).

Presentasi dokter tersebut dianalisis melalui teori Dramaturgi dari Goffman dalam melakukan anamnesis di masa pandemi. Peneliti menganalisis bentuk konstruksi dokter dalam proses wawancara medis kepada pasien, hal ini diharapkan dokter mampu membuka diri dan mendapatkan informasi yang benar terhadap penyakit yang diderita pasien melalui pertunjukan-pertunjukan tenaga Kesehatan dokter di dalam ruangan pemeriksaan.

Pada suatu proses komunikasi semua manusia memiliki mental, kemauan, dan kemampuan untuk dapat berkomunikasi dengan baik, serta mengevaluasi lawan berkomunikasi. Strategi komunikasi yang baik dalam mencapai tujuan harus bersifat maksimal dalam berkomunikasi, berarti berbicara tentang strategi komunikasi terdapat individu yang memulai interaksi, lalu pesan dikirim kepada individu yang lain melalui saluran dan mengharapkan umpan balik sebagai evaluasi dari tujuan mengapa komunikasi itu dilakukan. Dari unsur-unsur ini, strategi komunikasi dipilih dapat berfungsi efektif. Tujuankomunikasi dapat disepakatiketika individu memahami arti pesan dari individu lain dan perhatian juga menerima pesan sepenuhnya.

Liliweri (2003) mengutip itu beberapa hal yang meningkatkan kredibilitas seorang individu lainnya, antara lain otoritas dan kompetensi, yang merupakan tingkat kompetensi atau kompetensi seseorang untuk ditransfer pesan dalam proses komunikasi. Karakter yaitu sifat yang mendalam pada proses komunikasi, seperti cara menampilkan dirinya. Orang-orang yang melihat memiliki perasaan positif, dampaknya ide yang dimunculkan mudah disepakati, diselesaikan, dan dipercaya. Karisma atau kemampuan seseorang individu dapat menampilkan dirinya sebagai seorang tokoh yang memiliki kualitas baik. 


\section{Sipa' Sipakatau}

Kelompok etnis terbesar di wilayah Sulawesi Selatan yang menjunjung tinggi persaudaraan atau persahabatan atas kesadaran persatuan etnis adalah Suku Bugis. Mattulada (1974) mengemukakan sejarah bahwa bentuk masyarakat Bugis harus mengonstruksi diri dalam bertingkah laku kepada sesama, istilah tersebut dinamakan pangngadereng yang diubah menjadi sikap hati. Pangngadereng dalam suku Bugis terdiri dari empat unsur, yang pertama adalah ade' (kasih sayang), kedua adalah bicara (tutur kata), selanjutnya rapang (pengorbanan), dan yang terakhir adalah wari' (kebajikan).

Ade' diartikan sebagai belas kasihan, bicara berarti saling memaafkan sesama manusia, rapang untuk saling memberikan pengorbanan demi sang leluhur, dan wari' sebagai pengingat dalam melakukan tindakan kebajikan. Hal ini telah dijelaskan oleh para ahli kitab Lontara. Unsur-unsur tersebut harus ditanamkan ke dalam diri masyarakat ketika berinteraksi kepada sesama. Budaya lokal pada umumnya memberi pengaruh positif pada kehidupan manusia, proses internalisasi budaya lokal dalamkegiatan manusia merupakan salah satu bentuk strategi tercapainya proses pertukaran informasi antara manusia.

Teori Ekologi Manusia memiliki hubungan timbal balik antara lingkungan dengan perilaku. Terkait dengan pembentukan dan pengembangan kearifan lokal, maka bagian emosi ini memberikan dorongan kepada manusia untuk melakukan sesuatu sesuai dengan kebutuhannya (Ridwan, 2007).

Nilai-nilai budaya masih jelas tercermin pada pergaulan sehari-hari masyarakat BugisMakassar di manapun berada. Erman Syarif menjelaskan bahwa dalam kebudayaan BugisMakassar dikenal tiga sipa' (Sipakatau 'saling memanusiakan",Sipakainge '(salingmengingatkan", dan Sipakalebbi' "saling menghormati") yang dapat menjadi pedoman dalam kehidupan sosial masyarakat Bugis-Makassar. Sipakatau dalam falsafah Bugis-Makassar yang merupakan sifat yang bertujuan untuk memanusiakan manusia, pada intinya individu harus saling menghormati sesama manusia dalam keadaan apapun (Syarif, Sumarmi, Fatchan, \& Astina, 2016).

Wujud dari nilai sifat Sipakatau dipahami oleh seorang berstatus sosial atau pekerjaan yang lebih tinggi memperlakukan bawahan, budak, atau orang yang lebih rendah dengan tidak semena-mena. Seorang yang memiliki status sosial yang lebih tinggi berkewajiban untuk memperlakukan bawahannya dengan layak.

Sifat budaya lokal dapat diterapkan pada institusi kesehatan. Nilai budaya tersebut dapat memengaruhi cara seseorang berinteraksi dalam kehidupan, termasuk dalam dunia kerja yang bertujuan sebagai bentuk tercapainya komunikasi efektif.

Tenaga medis berkomunikasi dengan pasien sepatutnya menggunakan nilai-nilai budaya lokal, agar komunikasi keduanya berjalan sesuai tujuan yang diharapkan. Secara umum, budaya lokal memiliki dampak positif pada pembentukan kepribadian manusia, karena dapat digunakan sebagai alat kontrol diri dan mengontrol orang lain. Manusia memiliki kontrol diri yang baik selalu sadar tentang hal yang diizinkan dan tidak boleh dilakukan saat menjalankan tanggung jawab. Budaya memiliki pengaruh kuat yang mendasari perilaku manusia, penerapan nilai-nilai dalam sosial, dan terciptanya proses interaksi yang mewariskan kepada anggota organisasi khususnya kedokkteran (Jamaluddin et.all, 2017; Aini et.all, 2011).

Dokter merupakan tenaga kerja kesehatan profesional yang berusaha untuk menjaga kesehatan dan mengharapkan pemulihan atau penyembuhan dari penyakit yang diderita. Tidak hanya hubungan fungsional yang dibangun dengan pasien, tetapi juga hubungan emosional dalam proses pemberian layanan (Hersavira, 2019). Profesi yang elit merupakan gelar yang telah dikonstruksi oleh masyarakat tentang profesi dokter. Banyak orang tua mengharapkan 
anak untuk menjadi dokter, tetapi dokter juga orang biasa yang memiliki kehidupan masyarakat di luar profesi. Dokter memiliki peran penting dalam proses penggalian informasi keluhan dalam mendiagnosis penyakit seorang pasien. Proses anamnesi dokter mencari tahu tentang keluhan, usia, riwayat perjalanan, riwayat penyakit bawaan, gender, pekerjaan, dan domisili (Burns, Korn, Whyte, Thomas, \& Monaghan, 2011).

Komunikasi dapat memberikan informasi tentang penyakit yang diderita pasien disebut anamnesis. Proses ini melibatkan dokter dan pasien dalam suatu kegiatan komunikasi interpersonal. Proses anamnesis membantu dokter dalam membuka diri pasien ketika menjelaskan keluhannya. Dibutuhkan waktu, kesabaran, dan sikap perhatian oleh dokter dalam menjalani proses anamnesis dengan pasien. Proses anamnesis merupakan hal yang sangat rahasia dan menjadi etika dokter dalam menjaga privasi pasien, maka dari itu sebaiknya dilakukan di tempat tersendiri, agar tidak terdengar oleh orang lain. Banyak pasien yang tidak senang penyakitnya diketahui oleh orang lain. Proses anamnesis didapatkan dengan valid sesuai dengan kemampuan komunikasi yang baik seorang dokter terhadap pasiennya. Dokter mengendalikan proses komunikasi dengan membangun interaksi yang baik, sehingga tidak ada kekeliruan yang terjadi dalam proses anamnesis tersebut. Pada hakekatnya dokter dan pasien berkomunikasi untuk melakukan pertukaran informasi, menciptakan suatu hubungan interpersonal yang baik, dan pengambilan diagnosa dalam hal ini berkaitan dengan keputusan medis.

Pengambilan anamnesis dapat dilakukan dengan metode (Smith, 2009), yaitu 1) dokter memberi kesempatan pasien untuk mengemukakan semua keluhan serta kelainan yang dideritanya secara bebas; dan 2) memberikan pertanyaanpertanyaan seputar keluhan sehingga pasien dapat dituntun untuk mengemukakan semua keluhannya. Pasien memiliki cara yang berbeda dalam mengemukakan keluhannya, yaitu menceritakan seleuruh keluhan, pasien yang terlalu berlebihan atau cenderung tidak jelas dalam menceritakan keluhannya. Sedikit pasien yang dapat mengemukakan keluhannya dengan seksama, logis dan hati-hati karena ketakutan diagnosa penyakit yang diderita (Attala N, et al., 2010). Pengumpulan informasi pasien berupa data atau fakta diri pasien mencakup kondisi psikologis, sosial, dan biologis. Informasi tentang kondisi pasien dalam komunikasi kesehatan diperlukan agar dokter mengerti hal-hal apa yang dibutuhkan oleh pasien, sehingga dokter mampu mendiagnosis dan menyimpulkan penyakit yang diderita pasien setelah proses anamnesis. Pembuatan rencana tindakan dilakukan oleh dokter bersama dengan pasien untuk menanggapi masalah-masalah yang ada pada diri pasien dengan menjalin komunikasi antarpribadi antara dokter dan pasien.

Di masa pandemi, isolasi menyebabkan pasien takut terhadap COVID-19 dan menghambat proses pembukaan diri pasien. Pasien takut didiagnosis terpapar virus tersebut. Penghambat tersebut mampu berpotensi mengakibatkan wabah COVID-19 tidak terkendali akibat ketidakterbukaan pasien (Ramadhan et. all, 2020).

Peneliti menganggap program kesehatan dan siklus penyebaran penyakit dapat ditangani oleh komunikasi kesehatan. Hal ini dapat dikembangkan untuk membantu individu dalam mengubah perilaku menjadi lebih sehat berdampak kepada pasien. Kurangnya kualitas komunikasi yang baik antara dokter dan pasien, dan diagnosis yang tidak tepat dapat memperlambat penyembuhan penyakit.

Berdasarkan latar belakang, penelitian ini bertujuan menemukan strategi komunikasi interpersonal yang diterapkan oleh para dokter dalam proses anamnesis di masa pandemi COVID-19 Di Kota Makassar.

\section{Metode Penelitian}

Jenis penelitian yang digunakan yaitu deskriptif dengan metode kualitatif dengan pendekatan studi kasus komunikasi kesehatan COVID-19. Jenis pendekatan studi kasus membahas mengenai peristiwa dari seorang 
manusia baik secara individu, organisasi, dan kelompok yang bertujuan untuk mendapatkan analisis yang mendalam mengenai kasus yang diteliti. Penelitian studi kasus memiliki ciri khas adanya sebuah batasan, baik secara kasus, tempat maupun waktu yang di teliti. Studi kasus berlandaskan pada program, aktivitas, dan kejadian. (Herdiansyah, 2014) Peneliti menganggap bahwa riset ini cocok untuk dikaji melalui studi kasus karena aktivitas antara dokter dan pasien dalam proses anamnesis di masa pandemi di Kota Makassar membutuhkan strategi untuk membuka diri pasien.

Berfokus pada strategi komunikasi dokter yang menggunakan nilai-nilai lokal terhadap pasien pada proses anamnesis dan dimensi sosio budaya yang melatarbelakanginya. Riset ini dilakukan selama 1,5 bulan, dari bulan April 2020 sampai pertengahan Juni 2020 yang berlokasi di salah satu Rumah Sakit besar di Kota Makassar, Provinsi Sulawesi Selatan. Pemilihan lokasi tersebut atas dua pertimbangan; 1) Kota Makassar merupakan episentrum penyebaran virus corona di Provinsi Sulawesi Selatan dengan jumlah kasus Kota Makassar sebanyak 951 orang (SulseslTanggapCOVID-19, 2020); 2) Kota Makassar merupakan pusat perawatan pasien COVID-19, dan pusat rumah sakit rujukan dari setiap kabupaten di Sulawesi Selatan. Atas dasar kondisi tersebut maka diasumsikan bahwa tenaga medis memberikan respon yang sama terhadap strategi komunikasi dalam pembukaan diri pasien pada proses anamnesis.

Informan penelitian meliputi tenaga medis yang berprofesi sebagai dokter di poli RS X Kota Makassar sebanyak lima orang. Subjek penelitian berasal dari suku Bugis-Makassar yang telah menetap di Kota Makassar lebih dari 5 tahun. Kriteria dokter yang menjadi informan adalah dokter yang tidak menangani pasien COVID-19 dan bertugas di bagian poli. Peneliti tidak mengetahui data nama-nama tenaga medis yang berprofesi sebagai dokter di rumah sakit tersebut, maka peneliti menentukan subjek penelitian melalui teknik bola salju (snowball). Teknik tersebut diawali dengan informan satu secara bergulir ke informan berikutnya.

Teknik yang digunakan dalam pengumpulan data: a) Data primer, yang terdiri dari wawancara yang mendalam kepada informan secara daring video call di media sosial WhatsApp; b) Data sekunder diperoleh melalui literatur, jurnal, riset sebelumnya yang berkaitan dengan komunikasi kesehatan. Teknis analisis data yang digunakan adalah mengumpulkan data wawancara dengan informan, lalu data wawancara tersebut dipilah. Pemilahan data dilakukan dengan mereduksi data yang dipakai dan data yang menjadi data cadangan. Data tersebut disajikan ke dalam hasil penelitian dengan dianalisis menggunakan teori, konsep, dan hasil penelitian sebelumnya, serta menyimpulkan analisis hasil penelitian berupa temuan baru mengenai komunikasi kesehatan berbasis kearifan lokal Sipakatau.

\section{Hasil Penelitian dan Pembahasan}

Hasil wawancara yang dilakukan oleh peneliti, kelima informan mengatakan bahwa bentuk strategi komunikasi interpersonal yang dilakukan oleh tenaga medis dokter menggunakan strategi komunikasi Sipakatau. Dokter-dokter yang menjadi subjek penelitian menyadari bahwa penggunaan nilai Sipakatau dapat membantu dokter dalam membuka diri serta membangun kepercayaan pasien saat proses anamnesis.

Berdasarkan pendekatan Dramaturgi, penelitian ini menujukkan bahwa dokter mempunyai dua panggung dalam kehidupannya. Panggung ini berupa panggung depan (front stage) di masa pandemi dan panggung belakang (back stage) sebelum masa pandemi.

\section{Front Stage Dokter di masa Pandemi COVID-19}

Bentuk refleksi diri yang keluar dari diri seseorang adalah sebuah penampilan dan menjadi sebuah alat komunikasi antar individu. 
Setiap orang memiliki penampilan yang berbeda dalam mempresentasikan dirinya di depan orang banyak, salah satunya profesi dokter, salah satu profesi profesional kesehatan yang mempunyai penampilan yang cukup menarik dari pada tenaga kesehatan lainnya lainnya. Penampilan dokter yang elegan dan rapi dengan jas putih di tubuhnya, alat stetoskop menggantung di lehernya, penampilan stylish dari sepatu sampai model rambut atau jilbab merupakan penampilan yang unik untuk ditampilkan di depan khalayak sebelum masa pandemi. Seperti yang disampaikan oleh informan dr. GPR yang mengatakan bahwa: "Sebelum masa pandemi, biasanya kami menggunakan banyak alat, seperti stetoskop di leher, peralatan medis di atas meja dan menggunakan ki jas dokter. Tetapi pada masa pandemi sekarang kami dokter yang bertugas disini sepakat untuk tidak menampakkan banyak peralatan medis di badan, karena kami mau pasien yang datang itu nyaman dengan kami agar tidak ada gap antara dokter dan pasien. Yahh... paling kami menggunakan alat masker dan face shield untuk melindungi diri dari para carrier virus corona ... jasku biasanya saya gantung ji didekatku terus paling saya pake papan namaku (name tag) di kemeja supaya sebagai identitas pengenalku sebagai dokter yang bertanggung jawab pada jam operasional hari itu." (wawancara dengan $\mathrm{dr}$. GPR pada bulan Mei 2020 di Kota Makassar)

Penampilan dokter yang sederhana menghasilkan pengelolaan kesan bagi pasien yang melihatnya, dokter mempunyai dua kehidupan sosial jika dilihat dari penampilan yang ditampilkan sekarang, yaitu front stage yaitu pada masa pandemi dan backstage sebelum masa pandemi. Kedua panggung tersebut mempunyai perbedaan jika dilihat dari panggung belakang dan panggung depannya. Penampilan yang rapi dan terkesan memiliki kelas tersendiri berbeda jika dilihat dari wilayah waktu yang berbeda, sejalan dengan teori Dramaturgi Goffman yang membagi kehidupan sosial dalam berinteraksi di waktu tertentu.
Masyarakat Bugis-Makassar sangat menjunjung tinggi sipa' dalam mabbicara, Adanya pengertian sikap di atas menunjukkan bahwa sikap dapat memengaruhi tindakan individu kepada suatu objek, maupun diri sendiri. Sikap merupakan suatu pola perilaku, tendensi atau kesiapan antisipatif, dalam menyesuaikan diri dalam situasi sosial secara sederhana hal ini telah dijelaskan oleh La Pierre (Azwar, 2007).

Presentasi diri yang dilakukan oleh dokter, menghasilkan pengelolaan kesan, salah satunya sikap dan perilaku dokter kepada pasien terhadap penampilannya. Sikap tersebut timbul sesuai dengan keadaan yang terjadi, dokter juga menghasilkan sikap untuk orang disekitarnya, sikap yang dokter tampilkan sesuai dengan harapan pasien sehingga dapat membangun kepercayaan dan terbuka kepada dokter sesuai dengan tampilan dokter. Pengelolaan kesan dilihat dari sikap dokter kepada masyarakat yang seperti disampaikan oleh dr. $\mathrm{OH}$. "Alhamdulillah... setelah kami menggunakan strategi tersebut, para pasien yang datang kepada kami dapat na ungkapkan mi dirinya ketika waktu proses anamnesis, walaupun pertamanya mereka agak canggung dan terlihat tertutup. Tapi setelahnya diaplikasikan strategi di masa pandemi ini, mereka pelan-pelan bisa membuka dirinya" (wawancara dengan dr. $\mathrm{OH}$ pada bulan Mei 2020 di Kota Makassar) Penjelasan dari dr. $\mathrm{OH}$ dapat disimpulkan bahwa sikap yang dihasilkan dokter di masa pandemi mampu membuka diri pasien pada proses anamnesis. Perilaku dokter tersebut dipandang baik oleh pasien, tetapi saat pasien cenderung tertutup dan terkesan menjaga jarak, maka dokter membangun strategi-strategi lain agar tujuan dari penggalian informasi pasien terwujud. Goffman telah menjelaskan dalam teorinya bahwa presentasi diri berfungsi untuk membuat kesan yang diharapakan muncul pada orang lain. Kesan yang dimaksud adalah rasa nyaman dan setara, sehingga pasien mampu membuka diri untuk memberikan informasi. 
Penjelasan dari dr. $\mathrm{OH}$ sebagai informan penelitian dipertegas dengan adanya penjelasan yang sama dari dr. AH, sebagai berikut. "Biasanya itu pasien toh! cenderung tertutup ketika mereka punya sesuatu yang negatif dalam dirinya, misalnya pasien tersebut baru pulang dari pulau jawa, atau memiliki penyakit bawaan. Nah... pada posisi itulah kami memakai strategi-strategi lain seperti menyuguhkan minuman atau makanan kepada pasien yang datang. Proses anamnesis saya tidak dilakukan secara poin-poin, tetapi sebisa mungkin mengambil informasi awal dengan cara bercerita mengenai hal yang disukai oleh pasien seperti pekerjaannya, setelah dari itu saya menyangkut pautkan hal tersebut masuk ke dalam step keluhan yang dirasakan, misalnya dia bekerja sebagai pedagang, dia terserang batuk dan demam, maka saya tanyakan kondisi lingkungannya. Proses anamnesis tidak kaku dengan melakukan empat mata saja dalam satu ruangan. Menggunakan bahasa lokal yang sopan seperti ki' atau kita', sebisa mungkin tidak menggunakan kata-kata yang menekan pasien dalam menggali informasi. Serta tidak memanggil pasien dengan panggilan pak atau ibu, tetapi saya mengkondisikan sesuai umur, jika lebih tua dari saya saya memanggilnya dengan puang, deng atau daeng, dan kareng atau karaeng. Sedangkan jika pasien tersebut lebih muda dari saya saya akan memanggilnya dengan sapaan ndi' atau andi'," (wawancara dengan dr. AH pada bulan Mei 2020 di Kota Makassar).

Strategi komunikasi interpersonal antara dokter pasien di panggung depan dijelaskan pada tabel 1 .

Tabel 1 menjelaskan bahwa tenaga kesehatan dokter menggunakan beberapa strategi dalam proses anamnesis. Terlihat bahwa dokter memulai interaksi dengan menanyakan kegiatan pasien di lingkungan dengan menggunakan sapaan yang sopan dan tidak membuat jarak kepada pasien tersebut. Pada tahapan mengenal individu, dokter dianjurkan untuk memulainya dengan memancing pasien untuk bercerita tentang kegiatan kesehariannya. Proses dimulai dengan pasien bercerita dokter harus memusatkan perhatian secara penuh kepada pasien guna kepercayaan yang telah pasien berikan kepada dokter sebagai tempat berbagi tidak mengecewakan pasien. Tujuandaripendekatan ini adalah agar dokter mudah membuka diri pasien.

Di front stage merupakan dunia profesional para dokter, saat berada di ruangan pemeriksaan, para dokter mengkonstruksi diri untuk mendapatkan kepercayaan sehingga pasien dapat membuka dirinya pada proses anamnesi. Penampilan dokter yang berubah-ubah sesuai dengan konteksnya telah dijelaskan oleh Goffman dalam teorinya bahwa seseorang memainkan peran seperti layaknya dalam sebuah drama. Dramatersebutberubah-ubah sesuaidenganperan yang mainkan, hal ini seperti presentasi dokter ketika sebelum masa pandemi dan masa pandemi.

Panggung depan Goffman juga berfungsi untuk membangun citra seseorang dalam berinteraksi dengan orang lain. Hal tersebut sejalan dengan penelitian ini, presentasi dokter dikonstruksi untuk membangun keperceayaan pasien untuk terbuka pada proses anamnesis, serta membangun citra positif kepada masyarakat untuk tidak ragu ataupun takut ke rumah sakit. Front stage dokter dengan strategi-strateginya mampu berhasil membangun citra positif untuk membangun kepercayaan dan membuka diri pasien dimasa pandemi (Kholisoh, 2015).

\section{Back Stage Dokter sebelum Pandemi COVID-19}

Panggung belakang merupakan panggung pribadi bagi para dokter, panggung yang tidak boleh diketahui oleh orang lain. Dalam panggung belakang dokter mempresentasikan dirinya dengan menampilkan kesan dan perilaku yang hampir sama dari panggung depan. Di area panggung belakang seorang dokter cenderung menunjukkan sifat aslinya dalam lingkungan sekitarnya. Seperti yang disampaikan oleh dr. FR yang merasa tidak ada bedanya ketika dr. FR menjadi seorang dokter dengan orang biasa, tetapi pada saat itu dia berperan sebagai penggali informasi pasien. 
Tabel 1. Strategi Dokter di Masa Pandemi

\begin{tabular}{|c|c|c|}
\hline No. & $\begin{array}{l}\text { Inisial Subjek } \\
\text { penelitian }\end{array}$ & Strategi Komunikasi Panggung Depan Di masa Pandemi \\
\hline 1. & dr. $\mathrm{AH}$ & $\begin{array}{l}\text { 1. Menyuguhkan minuman atau makanan kepada pasien yang } \\
\text { datang. } \\
\text { 2. Proses anamnesis saya tidak dilakukan secara poin-poin, tetapi } \\
\text { sebisa mungkin mengambil informasi awal dengan cara bercerita } \\
\text { mengenai hal yang disukai oleh pasien seperti pekerjaannya, } \\
\text { setelah dari itu saya menyangkut pautkan hal tersebut masuk ke } \\
\text { dalam step keluhan yang dirasakan (misal; dia bekerja sebagai } \\
\text { pedagang, dia terserang batuk dan demam, maka saya tanyakan } \\
\text { kondisi lingkungannya). Proses anamnesis tidak kaku dengan } \\
\text { melakukan empat mata saja dalam satu ruangan. } \\
\text { 3. Menggunakan bahasa lokal yang sopan seperti } k \text { ' atau kata', } \\
\text { sebisa mungkin tidak menggunakan kata-kata yang menekan } \\
\text { pasien dalam menggali informasi. Serta tidak mernanggil pasien } \\
\text { dengan panggilan pak atau ibu, tetapi saya mengkondisikan sesuai } \\
\text { umur, jika lebih tua dari saya saya memanggilnya dengan puang } \\
\text { (sapaan Bugis), deng atau daeng (sapaan Makassar), dan kareng } \\
\text { atau karaeng (sapaan Makassar-Jeneponto). Sedangkan jika } \\
\text { pasien tersebut lebih muda dari saya, maka yang saya lakukan } \\
\text { adalah memanggilnya dengan sapaan ndi atau andi } \\
\text { (Bugis\&Makassar). }\end{array}$ \\
\hline 2. & dr. FR & $\begin{array}{l}\text { 1. Menyajikan minuman atau makanan untuk pasien yang datang. } \\
\text { 2. Proses pencatatan riwayat saya tidak dilakukan sceara langsung, } \\
\text { tetapi scbanyak mungkin untuk mengambil informasi awal dengan } \\
\text { berbasa-basi tentang hal-hal yang diminati oleh pasien seperti } \\
\text { hobi, setelah itu saya menghubungkannya ke dalam hal-hal yang } \\
\text { terkait dengan poin-poin anamnesis } \\
\text { 3. Menggunakan bahasa lokal yang sopan kepada pasien untuk } \\
\text { membuat mereka nyaman. }\end{array}$ \\
\hline 3. & dr. GPR & $\begin{array}{l}\text { 1. Menawarkan minuman dan makanan kepada pasien } \\
\text { 2. Tidak membuat jarak pada pasien, dengan menggunakan APD } \\
\text { saya berusaha menjelaskan mengapa saya menggunakan seragam } \\
\text { ini dengan tidak menakut-nakuti pasien agar mereka dapat nyaman } \\
\text { dan tidak takut untuk memberikan informasi mengenai keluhan } \\
\text { dirinya. } \\
\text { 3. Menggunakan bahasa yang sopan, dan memakai sapaan Bugis- } \\
\text { Makassar. }\end{array}$ \\
\hline 4. & dr. AAM & $\begin{array}{l}\text { 1. Menyuguhkan makanan atau minuman kepada pasien. } \\
\text { 2. Proses amamnesis dimulai dengan mengobservasi pasien untuk } \\
\text { melihat keluhan-keluhan yang terlihat oleh mata. } \\
\text { 3. Menggunakan bahasa yang sopan dan dimengerti oleh pasien agar } \\
\text { pasien tidak bingung dan terbuka dalam proses anamnesis nya. }\end{array}$ \\
\hline & dr. $\mathrm{OH}$ & $\begin{array}{l}\text { 1. Menanyakan kabar pasien dengan menggunakan kata yang sopan } \\
\text { dan sapaan orang Bugis-Makassar. } \\
\text { 2. Menyuguhkan makanan atau minuman kepada pasien. } \\
\text { 3. Proses anamnesis dimulai dengan mengobservasi pasien untuk } \\
\text { melihat keluhan-keluhan yang terlihat olch mata. Seperti kondisi } \\
\text { pasien yang lemah, dengan memberikan pertanyaan "nda' } \\
\text { begadang jelik semalam puang?"' (apakah bapak begadang } \\
\text { semalam?). Diharapkan pasien memberikan jawaban yang sesuai } \\
\text { dengan yang dialaminya. }\end{array}$ \\
\hline
\end{tabular}

Sumber: Hasil wawancara (2020)

"Kayak samaji kurasa diriku ketika tidak menjadi dokter ka di rumah sakit, karena saya pake pakean yang biasa tidak pake jas dokter, jasku saya gantung ji disampingku terus saya pakai kemeja biasa, sama dengan pasien. Cuman kan kita sebagai dokter harus lebih peka dan aktif dalam menggali informasi pasien" (wawancara dengan dr. FR pada bulan Mei 2020 di Kota Makassar) Hasil wawancara kepada informan penelitian menunjukkan bahwa penampilan para dokter saat di panggung belakang sebelum pandemi hampir sama dengan ketika berada di panggung depan. Celana jeans atau rok rempel, baju kemeja sama saat di panggung depan para dokter tidak menampilkan sesuatu yang berlebihan di depan pasien. Panggung belakang berfungsi untuk memenuhi kebutuhan personal seseorang.

Bertindak tanpa dibuat-buat yang mencerminkan keaslian individu menjadi ciri khas dari fornt stage. Penjelasan yang diberikan dr. FR menjelaskan bahwa dokter tidak memperlihatkan perbedaan yang banyak dalam proses anamnesis dimasa pandemi, tetapi seperti yang disampaikan oleh informan dr. FR bahwa dimasa pandemi dokter dituntut lebih peka dan aktif dalam menggali informasi dari pasien. Hal tersebut didukung oleh strategi yang dilakukan dokter dalam membuka diri pasien dalam proses anamnesis.

\section{Strategi Komunikasi Dokter menggunaka Kearifan Lokal Sipa' Sipakatau}

Penampilan yang disuguhkan saat di panggung depan (front stage) merupakan panggung tempat para dokter beraksi di dalam menunjukkan penampilan dokter yang sederhana yang dalam konsep Sipakatau. Nilai sifat Sipakatau yang dipahami itu terlihat ketika seorang manusia yang derajat status sosial atau pekerjaan yang lebih tinggi memperlakukan 
bawahannya, budak atau orang yang lebih rendah dengan tidak semena-mena dan sebisa mungkin setara dengan orang lain. Sejalan dengan penelitian ini bahwa dengan memberikan perhatian, memperlakukan pasien sebagai raja, para tenaga medis telah menerapkan komunikasi dengan konsep sikap Sipakatau. Penelitian ini mendukung penelitian Setyorini (2019) yang mengatakan bahwa kesetaraan berarti pengakuan bahwa kedua pihak antara dokter dan pasien saling memiliki nilai, dan berharga serta masing-masing pihak mempunyai sesuatu yang penting untuk disumbangkan. Sumbangan yang dimaksud adalah informasi, dokter menganggap informasi dari pasien sangat berharga sebagai langkah awal keberhasilan dalam mendiagnosis.

Komunikasi yang dijalani dokter dan pasien dalam tahap wawancara medis merupakan suatu pola komunikasi interaksional yang memiliki fungsi sebagai pencari informasi keluhan pasien. Komunikasi ini bisa terwujud ketika pasien sakit dan mengunjungi dokter lebih terbuka dalam menyampaikan keluhannya. Hal yang terjadi di masyarakat di masa pandemi pasien cenderung tertutup dalam proses komunikasinya, ini dikarenakan pasien takut mendapatkan diagnosa dari dokter bersifat negarif.

Komunikasi Sipakatau merupakan cara atau strategi dokter dalam membuat pasien merasa dihargai dan nyaman ketika mengunjungi dokter. Komunikasi ini bertujuan untuk menghindari kesalahan dalam mendiagnosis penyakit pasien, maka dokter diharapkan mampu mengendalikan dan membawa proses komunikasi ke arah interaksi yang baik.

Kompetensi komunikasi yang baik mampu membantu dokter dalam memecahkan masalah kesehatan pada pasien, meningkatkan kepatuhan dari pasien dan mengurangi keraguan pasien merupakan proses komunikasi yang efektif. Hal ini dapat mendatangkan manfaat dalam menjalin hubungan interpersonal dokter dan pasien. Kedua pihak merasa saling memahami, pihak pasien merasakan rasa aman dari treatment-treatment yang diberikan dokter dan melakukan hal yang terbaikuntukpasiennya.Pasien harusmemberikan informasi yang benar dalam rangka keberhasilan dokter dalam mendiagnosis. Keduanya saling terhubung dan sudah menjadi sebuah pola komunikasi yang baik dalam proses anamnesi.

Dokter pada proses anamnesis mampu memenuhi kebutuhan untuk mendapatkan informasi, sebab dalam mendapatkan informasi tenaga kesehatan memainkan peran-peran dalam berinteraksi. Hal ini didukung oleh penelitian Kurniawan (2019) yang menemukan bahwa pasien terbuka pada proses anamnesis dapat mengatasi masalah kesehatan dan memberikan kesembuhan.

Pada strategi masing-masing dokter, maka jenis komunikasi yang digunakan adalah komunikasi Sipakatau. Sejalan dengan penelitian ini di mana dokter yang memiliki status tinggi dari pasien sebisa mungkin tidak menekan, tidak ada jarak, posisinya tidak lebih tinggi dari pada pasien. Misalnya memanggil dengan sapaan puang (sapaan Bugis), deng atau daeng (sapaan Makassar), dan kareng atau karaeng (sapaan Makassar-Jeneponto). Komunikasi yang baik antara dokter dengan pasien harus diperlukan terutama dalam masa pandemi COVID-19, dikarenakan dengan komunikasi yang baik dapat terbangun kepercayaannya dari pasien, sehingga terbuka kepada tenaga medis saat proses wawancara medis. Selaras dengan penelitian Setyorini (2019) bahwa anamnesis yang efektif adalah ketika ada kesetaraan, empati, dan dukungan. Penelitian ini juga menemukan proses komunikasi dokter dan pasien di Rumah Sakit $\mathrm{X}$ dapat membangun kesetaraan dengan pasien saat proses anamnesis. Kesetaraan terdapat dalam komunikasi Sipakatau yang berarti saling memanusiakan, sikap saling menghargai satu dengan yang lain. Cara berkomunikasi dengan menggunakan Ade' dan menerapkan sipa' Sipakatau pada bentuk profesi apapun (Kaddi \& Dewi, 2017) masyarakatnya bekerja. Jiwa masyarakat Bugis-Makassar menerapkan nilai tersebut sebagaimana layaknya manusia berperilaku sesamanya. 
Dokter menjadi kunci pasien dalam terdiagnosis penyakit tertentu dengan mengumpulkan informasi-informasi dan memeberikan perhatian yang baik. Perhatian dokter berlaku untuk semua pasien, tidak terkecuali penyandang penyakit tertentu di Rumah Sakit X Kota Makassar. Semua pasien yang datang untuk mengkonsultasikan dirinya mendapatkan perhatian yang baik dari setiap dokter yang menanganinya.

Kepercayaan menjadi poin penting dalam strategi komunikasi yang dilakukan oleh dokter, sehingga hal tersebut menentukan proses komunikasi dapat berlanjut atau tidak. Kepercayaan adalah tindakan penerimaan yang digunakan bersama sebagai sesuatu sah dan benar dan kepercayaan juga berarti menerima ketulusan orang yang menggunakan informasi bersama (Kurniawan, 2019). Terdapat dua jenis hal yang dipercaya; pesan tepercaya dan sumber pesan dipercaya (Kincaid \& Schramm, 1987). Strategi di masa pandemi sekarang merupakan perencanaan dan manajemen tenaga medis dokter untuk mencapai tujuan anamnesis pasien. Penggunaannilai-nilailokaldalamberkomunikasi serta sikap yang ditampilkan dokter di panggung belakang dan panggung depan menimbulkan kesan serta perilaku yang bersifat positif. Pasien membangun kepercayaan dan membuka diri kepada dokter dengan mempertimbangkan penampilan serta cara memperlakukan pasiennya.

Doktermenetapkan rencana sebagai gambaran untuk langkah-langkah atau kegiatan komunikasi yang dilakukan untuk mencapai tujuan yang diharapkan. Langkah awal yang dilakukan oleh dokter yaitu dengan merumuskan strategi komunikasi Sipakatau dengan mengenal pasien secara lebih dekat di mana pasien sebagai sasaran utama komunikasi sifatnya tidak pasif. Dokter harus membangun berbagai pendekatan dengan pasien supaya pasien menjadi terbuka dengan dokter. Salah satu cara yang bisa digunakan adalah dengan menggunakan komunikasi Sipakatau.
Penggalian informasi pada proses anamnesis, pasien sedang dalam keadaan tenang dan tidak tertekan. Seperti yang disampaikan oleh dr. AAM pada wawancaranya yang mengatakan bahwa: "kita sebagai dokter di masa pandemi ini memiliki resiko tinggi tertular virus corona ini, karena orang-orang yang datang kepada kami pastilah orang memiliki gangguan dalam kesehatannya. Tidak mungkin mi orang yang sehat mau datang ke rumah sakit, itu sudah menjadi hukum kesehatan, yang tergantung orang itu mau datang ke dokter atau ke dukun ... maka dengan itu kami sepakat untuk mengubah strategi pada proses anamnesis yang tidak terlalu kaku dan tidak membuat pasien menjadi tertekan dan akhirnya menutup diri mereka, karena masa sekarang orang berpikir dua kali untuk ke rumah sakit, dan pasti stigma mengenai virus ini dan berita hoax yang tersebar mengenai kalau orang sudah positif pasti tidak akan pulang mi ke rumahnya jika mereka punya penyakit bawaan. Alasan ini mi yang menjadi acuan kita dalam merancang strategi kesetaraan kepada pasien, menganggap mereka adalah keluarga dan tidak memperlihatkan adanya batasan antara dokter dan pasien" (wawancara dengan dr. AAM pada bulan Mei 2020 di Kota Makassar) Sejalan dengan apa yang disampaikan dr. AAM bahwa dokter dapat dipercaya oleh pasien, hal tersebut dapat memudahkan dalam memengaruhi penggalian informasi pada proses anamnesis. Langkah selanjutnya dalam perumusan strategi adalah menyusun pesan setelah mengenal pasien, adapun langkah itu adalah menentukan tema dan materi. Syarat utama dalam memengaruhi pasien dari pesan tersebut adalah mampu membangkitkan perhatian pasien. Ada dua strategi yang dokter terapkan dalam menyusun pesan, tetapi terkadang dokter juga mengalami hambatan seperti kesalahpahaman antara apa yang dokter maksud dengan apa yang dipahami oleh pasien. Pesan dokter yang kurang dipahami menyebabkan pemahan pasien yang kurang jelas, hal tersebut dapat menyebabkan rendahnya pemahaman tentang penyakit (Sari \& 'Atiqoh, 2020). Seperti yang disampaikan dr. AH yang mengatakan bahwa: 
"Terkadang juga susah sekali ki menggali informasi dari pasien karena bahasa. Nah ... sebab itulah kami tim dokter sebisa mungkin pake bahasa lokal yang mudah dipahami oleh pasien karena kalau mereka tertutup kami sulit mendiagnosa secara benar penyakit pasien, nanti mereka telah terpapar virus corona tetapi tidak menceritakan kronologi perjalanannya. Kalau itu terjadi kami sebagai dokter juga tidak memvonis pasien jika tidak sesuai dengan keluhannya, mereka akan kami pulangkan dan pasien tersebut bisa saja menjangkiti orang lain ... lain cerita lagi kalau pasien itu terdiagnosa penyakit tertentu, pasti kami akan lebih berhati-hati dalam menyampaikan penyakitnya karena supaya pasien tidak stress dan mau menjalani pengobatan. (wawancara dengan dr. $\mathrm{AH}$ pada bulan Mei 2020 di Kota Makassar) Hambatan yang terjadi pada proses anamnesis dapat diatasi dengan strategi dokter dalam menggunakan bahasa dan isi pesan yang dimengerti oleh pasien. Dokter berusaha menjadi pemantik dan pendengar yang baik untuk tidak mempersempit ruang gerak kedua individu. Kegiatan anamnesis dilakukan oleh seorang dokter melalui tahapan proses pembukaan diri kepada pasien. Komunikasi yang terarah dengan baik dan fokus pada proses komunikasi dapat menciptakan hubungan kepercayaan. Kepercayaan pasien terhadap dokter merupakan sebuah modal dasar bagi dokter dan pasien dalam menjalin hubungan komunikasi antarpribadi diantara keduanya.

Nilai-nilai lokal dapat menjelma menjadi pokok pegangan hidup dalam berinteraksi dengan manusia lain. Unsur budaya yang sangat tertanam dalam kehidupan masyarakat Sulawesi Selatan seperti nilai Sipakatau yang mengandung esensi nilai-nilai luhur yang bersifat umum. Nilai tersebut teraktualisasi secara baik dalam kegiatan profesional dokter di masa pandemi COVID-19, dapat terlihat ketika mengenyampingkan sikap lebih tinggi dari orang lain dan menerapkan kesetaraan kepada sesama dalam berinteraksi merupakan tujuan dari nilai-nilai pangadereng.
Penggunaan Bahasa, saling memanusiakan manusia, memandang manusia lain dengan penuh martabat, hingga siapapun yang berada dalam kondisi tersebut merasa senang dan nyaman dengan orang lain. Keselarasan dan keharmonisan dapat tercipta jika sifat Sipakatau diterapkan dalam bersosialisasi dengan sesama manusia. Penelitian ini menemukan strategi baru komunikasi kesehatan dokter pasien dalam proses anamnesis yang menggunakan kearifan lokal Sipakatau di masa pandemi yang mengatur pola tingkah laku dokter dalam menangani pasien dalam mengungkapkan dirinya.

Nilai-nilai luhur yang terkandung dalam falsafah orang Bugis Makassar dapat diterapkan disemua lapisan masyarakat tanpa terkecuali. Manusia atau dalam falsafah Bugis-Makassar yang dikenal dengan "tau" yang merupakan pondasi utama dalam berkomunikasi kepada sesama pada nilai Sipakatau. Menjunjung tinggi pedonam konsep siri na pacce dan pemaknaan sebagai makhluk sosial, maka hal yang patut dilakukan adalah aktualisasi dalam penerapan nyata di kehidupan bermasyarakat (Salere, 2016).

Sikap nilai luhur terkait dengan Sipakatau dapat diterapkan dalam komunikasi kesehatan dan dapat menjadi strategi komunikasi harus menyesuaikan dengan situasi yang berada di satu kelompok masyarakat (Zulkarnain, Subejo, \& Hartono, 2017). Sikap memanusiakan dan setara dengan pasien sesuai dengan nilai-nilai yang dianut oleh masyarakat Bugis-Makassar (Kaddi \& Dewi, 2017).

Hasil pembahasan menemukan bahwa presentasi diri dokter menggunakan bahasa verbal dan nonverbal budaya lokal. Hal ini menunjukkan bahwa presentasi diri dokter saat di panggung belakang (backstage) dan panggung depan (frontstage) terdapat kesan yang positif, pasien yang terbuka dan nyaman kepada tim medis pada saat proses anamnesis. Sikap yang ditunjukkan dokter membuktikan bahwa dokter memiliki sifat Sipakatau dengan penampilan sederhananya dalam menghadapi pasien. Komunikasi kesehatan berbasis kearifan lokal Sipakatau 
merupakan konsep baru. Konsep komunikasi yang menggunakan kearifan lokal dalam hal ini sipa' Sipakatau dapat membantu dokter dalam proses anamnesis. Pesan-pesan yang dirancang menggunakan strategi komunikasi dapat mengubah kebiasaan masyarakat.

\section{Simpulan}

Berdasarkan hasil penelitian disimpulkan bahwa dokter menerapkan langkah-langkah perumusan strategi komunikasi Sipakatau kepada pasien yang datang ke rumah sakit relevan dengan perspektif Dramaturgi. Dramaturgi Goffman identik dengan panggung depan dan panggung belakang individu dalam berinteraksi. Pada penelitian ini, teori Goffman dapat diasumsikan bahwa panggung belakang (backstage) bisa diidentikkan dengan presentasi dokter saat menjadi orang biasa. Identitas sebagai dokter dapat dilihat sebagaimana yang terlihat saat seseorang berkunjung ke rumah sakit. Panggung depan (front stage) dapat diasumsikan presentasi dokter dimasa pandemi, denganmemainkan peran-peran untukmembuka dan mendapatkan informasi dari pasien.

Pertama, dokter merepresentasikan diri pada front stage dengan menggunakan pakaian yang sederhana dengan tujuan kesetaraan status identitas dengan pasien, memposisikan pasien lebih tinggi daripada diri dokter. Pada back stage, dokter tidak memperlihatkan sesuatu yang berbeda dengan panggung depan, hanya saja dokter menjadi seorang dalam menggali informasi tentang keluhan pasien.

Kedua, dokter menerapkan nilainilai lokal masyarakat Bugis-Makassar dalam strategi pada proses anamnesis pasien. Seperti tidak menggunakan sapaan Pak atau Bapak dan Ibu kepada pasien, tetapi dengan menggunakan sapaan lokal yang sopan seperti ki' atau kita', puang, deng atau daeng, dan kareng atau karaeng, dan ndi' ataupun andi'.
Pola perilaku dokter yang sopan dan menggunakan komunikasi Sipakatau mampu membuka diri pasien lebih rinci mengenai penyakitnya. Hal ini dikarenakan perilaku dokter yang ramah dalam penyampaian hasil pemeriksaan dapat membuat pasien lebih nyaman pada proses wawancara medis (anamnesis). Komunikasi yang tercipta antara dokter yang menganggap pasien itu sebagai keluarga membuat posisi antara dokter dan pasien tersebut menjadi seimbang. Sifat kepedulian dokter kepada pasien menimbulkan perasaan dihargai dan setiap pasien mau membuka diri, serta bahasa komunikasi berbasis lokal yang lebih bersahabat dan akrab. Langkah ini dipilih dokter saat berkomunikasi dengan pasien karena menimbulkan rasa nyaman pada diri pasien saat berkomunikasi.

Proses anamnesis pada pasien sangat membutuhkan strategi yang baik, dalam hal ini dokter harus memiliki cara-cara dalam mengungkapkan diri ataupun penyakit yang diderita seorang pasien sehingga diagnosa dokter tepat. Dokter sebagai profesi diharapkan mendiagnosis penyakit pasien dengan menerapkan strategi-strategi seperti yang dilakukan dokter RS. X di Kota Makassar.

Penerapan nilai dan bahasa lokal dalam proses anamnesis sebagai bentuk konsep etnomedis sangat perlu diterapkan pada proses anamnesis. Hal ini bertujuan agar kedepannya tidak ada lagi kesalahan diagnosis (malpraktik) dalam menentukan dan memberikan obat kepada pasien. Sebagai tambahan, strategistrategi komunikasi Sipakatau diharapkan untuk meningkatkan kenyamanan dan kesadaran pasien untuk berkunjung ke rumah sakit dan membuka diri pasien ketika wawancara medis.

Peneliti memberi rekomendasi kepada rumah sakit dan dokter agar menerapkan komunikasi kesehatan antara dokter dengan pasien berbasis kearifan lokal dalam proses anamnesis. Strategi komunikasi Sipakatau bermanfaat dalam 
pembukaan diri dalam menggalian informasi pasien dalam proses anamnesis, dengan harapan masyarakat memiliki keinginan untuk datang ke rumah sakit baik di masa pandemi ataupun tidak dengan persepsi citra dokter yang baik.

\section{Ucapan Terima Kasih}

Peneliti mengucapkan terima kasih kepada dokter yang bersedia diwawancarai via daring karena pandemi COVID-19.

\section{Daftar Pustaka}

Aini, N., Lestari, P., \& Hendariningrum, R. (2011). Hubungan Gaya Kepemimpinan Dan Budaya Organisasi Dengan Kinerja Karyawan Pt Adi Satria Abadi Yogyakarta. Jurnal Administrasi Bisnis, 9 (1), 64-78. Attal, N., Cruccu, G., Baron, R., Haanpää, M., Hansson, P., Jensen, T. S., Nurmikko, T., $\&$ European Federation of Neurological Societies (2010). EFNS guidelines on the pharmacological treatment of neuropathic pain: 2010 revision. European journal of neurology, 17(9), 1113-e88. https://doi. org/10.1111/j.1468-1331.2010.02999.x

Azanella, L.A. (2020, April 28). Ada 25 Dokter yang Meninggal Terkait Covid-19 di Indonesia, PB IDI Bentuk Tim Khusus. Kompas. com. Diambil dari https://www.kompas. $\mathrm{com} / \mathrm{tren} / \mathrm{read} / 2020 / 04 / 28 / 163240665 /$ ada-25-dokter-yang-meninggal-terkaitcovid-19-di-indonesia-pb-idi-bentuk

Azwar, S. (2007). Sikap Manusia Teori dan Pengukurannya. Yogyakarta: Penerbit Pustaka Pelajar. Burns, E., Korn, K., Whyte, J., Thomas, J., \& Monaghan, T. (2011). Oxford American Handbook of Clinical Examination and Practical Skills. New York: Oxford University Press. databook. (2020). Puluhan Dokter Meninggal dalam Pandemi Covid-19. Diambil 24 April 2020, dari https://databoks.katadata. co.id/datapublish/2020/04/21/puluhandokter-meninggal-dalam-pandemi-covid-19
Herdiansyah, H. (2014). Metodologi Penelitian Kualitatif untuk Ilmu-ilmu Sosial. Jakarta: Salemba Humanika. Hersavira, D. (2019). Dramaturgi Relasi Dokter dan Pasien di Rumah Sakit Daerah Dr. Zainoel Abidin Banda Aceh. Persepsi: Communication Journal, 2(2), 45-57. https://doi.org/10.30596/persepsi.v2i2.3941 Innayatillah, B. A. (2016). Penerapan Komunikasi Efektif Dokter Penyakit Dalam (Internis) Untuk Proses Anamnesis Dan Diagnosis Pada Pasien Penyakit Dalam Di Rumah Sakit Umum Dr. Zainoel Abidin Banda Aceh. Banda Aceh: Fakultas FISIPOL Universitas Syiah Kuala. Jamaluddin, Salam, R., Yunus, N. Akib, H. (2017). Pengaruh Budaya Organisasi terhadap Kinerja Pegawai pada Dinas Pendidikan Provinsi Sulawesi Selatan. Jurnal Ad'ministrare, 4(1), 25-34. https://doi.org/10.26858/ja.v4i1.3443 Kaddi, S. M., \& Dewi, R. S. (2017). Sipakatau, Sipakainge, Sipakalebbi, Sipattokong (Studi Komunikasi Antarbudaya Perantau Bugis di Kota Palu, Sulawesi Tengah). Prosiding Konferensi Nasional Komunikasi, 347. Jakarta: Ikatan Sarjana Ilmu Komunikasi. Khadijah, U. L., \& Rizal, E. (2015). Komunikasi Antara Dokter Dan Pasien: Studi Kasus Kegiatan Komunikasi Di Ruangan Praktek Antara Orang Tua Dan Dokter Untuk Penanganan Anak Berkebutuhan Khusus. Prosiding Simposium Nasional Komunikasi Kesehatan, 1027. Sumedang, Jatinangor: Fakultas Ilmu Komunikasi Universitas Padjadjaran. Kholisoh, N. (2015). Strategi Komunikasi Public Relations dan Citra Positif Organisasi (Kasus Public Relations Rumah Sakit "X" di Jakarta). Jurnal Ilmu Komunikasi, 13(3), 195-209. Diakses dari http://jurnal.upnyk.ac.id/ index.php/komunikasi/article/view/1459

Kincaid, D. L., \& Schramm, W. (1987). Asas-asas Komunikasi Antar Manusia. Jakarta: LP3ES bekerja sama dengan EAST-WEST Communication Institute. 
Kurniawan, B. C. (2019). Peran Anamnesis Terhadap Kesembuhan Pasien Cephalgia. Surakarta: Universitas Sebelas Maret. Lestari, P., \& Sularso. (2020). The COVID-19 Impact Crisis Communication Model Using Gending Jawa Local Wisdom. International Journal of Communication and Society, 2(1), 47-57. https://doi.org/10.31763/ijcs.v2i1.150

Liliweri, A. (2003). Dasar-Dasar Komunikasi Antarbudaya. Yogyakarta: Pustaka Pelajar.

Mattulada.(1974).Bugis-Makassar:Manusiadan Kebudayaannya. Depok : Jurusan Antropologi Fakultas Sastra Universitas Indonesia. Mulyana, D. (2008). Ilmu Komunikasi: Suatu Pengantar. Bandung: Remaja Rosdakarya.

Ridwan, N. A. (2007). Landasan keilmuan kearifan lokal. Jurnal Studi Islam dan Budaya, 5(1), 27-38. Taufiqqurahman, M. (2020, Mei 22). 16 Tenaga Kesehatan RS Wahidin Makassar Positif Corona. DetikNews.com. Diambil dari https://news.detik.com/ berita/d-5025252/16-tenaga-kesehatanrs-wahidin-makassar-positif-corona

Ramadhan, F., Aritonang, D. D., Arcana, P. F., \& Nusrat, M. (2020, Maret 26). Melacak Riwayat Kontak Pasien Covid-19. Kompas. com. Diambil dari https://kompas.id/ baca/humaniora/kesehatan/2020/03/26/ melacak-riwayat-kontak-pasien-covid-19/

Salere, S. (2016). Aktualisasi Pappaseng to Riolo Sipa' (Sipakatau, sipakalebbi dan sipakainge) di Pasar Tradisional Sulawesi Selatan. Diambil 25 April 2020 dari from http:// immajfeuh.org/category/uncategorized/ Salisah, N. H. (2011). Komunikasi Kesehatan: Perlunya Multidisipliner dalam Ilmu Komunikasi. Jurnal Ilmu Komunikasi, 1(2), 170-193. Sari, D. P., \& 'Atiqoh, N. S. (2020). Hubungan Antara Pengetahuan Masyarakat Dengan Kepatuhan Penggunaan Masker Sebagai Upaya Pencegahan Penyakit Covid-19 Di Ngronggah. INFOKES: Jurnal Rekam Medis dan Informatika Kesehatan, 10(1), 52-55. Setyorini,I.(2019).Efektifitas Komunikasi Dokter Dalam Membangun Kepercayaan Pasien (Studi Kasus Komunikasi Interpersonal Dokter Dan Pasien Di Klinik Nirmala Husada). Ponorogo: IAIN Ponorogo. Smith, H. (2009). Current Therapy in Pain. In: Smith H. Neuropathic Pain - Definition, Identification, and Implications for Research and Therapy. Philadelphia: Saunders Elsevier.

SulseslTanggapCOVID-19. (2020). Data Pantauan COVID-19 Di Sulawesi Selatan. Diambil 7 Juni 2020, dari https://covid19.sulselprov.go.id/data Syarif, E., Sumarmi, S., Fatchan, A., \& Astina, I. K. (2016). Integrasi nilai budaya etnis Bugis Makassar dalam proses pembelajaran sebagai salah satu strategi menghadapi era masyarakat ekonomi ASEAN (MEA). Jurnal Teori dan Praksis Pembelajaran IPS, 1(1), 13-20. http:// dx.doi.org/10.17977/um022v1i12016p013 Zulkarnain, M., Subejo, \& Hartono, S. (2017). Strategi Komunikasi dalam Membangun Kebiasaan Makan Pangan Lokal Percepatan Penganekaragaman dan Konsumsi Pangan di Kabupaten Bengkulu Utara. Jurnal Ilmu Komunikasi, 15(2), 177-188. Diakses dari http://jurnal.upnyk.ac.id/ index.php/komunikasi/article/view/2164 